\title{
The Dutch International Responsible Business Conduct Agreements
}

\author{
Effective Initiatives?
}

Martijn Scheltema*

\begin{abstract}
This contribution analyses the effectiveness of the Dutch International Responsible Business Conduct (IRBC) agreements and suggests some avenues for improvement. Several challenges in connection with effectiveness have been identified in evaluations of the IRBC agreements, and these are used as a starting point for the analysis. The focus is on three themes: (i) uptake, leverage and collaboration; (ii) implementation of OECD due diligence including monitoring and (iii) access to remedy. This contribution shows that low uptake may not be a sign of ineffectiveness per se, although in terms of leverage a sufficient number of participants or collaboration between agreements seems important. In connection with due diligence, it is recommended to align the implementation of OECD due diligence. Furthermore, an effective monitoring mechanism by a secretariat, as is currently implemented in the Textile agreement only, is most likely to bring about material changes in business behaviour. Other types of supervision seem less effective. Access to remedy poses a challenge in all IRBC agreements. It is recommended that the expectations the agreements have on access to remedy be clarified, also in connection with the role of signatories to the agreements in cases where they are directly linked to human rights abuse. Furthermore, it is recommended that a dispute resolution mechanism be introduced that enables complaints for external stakeholders against business signatories, comparable to that of the Textile agreement. However, rather than implementing separate mechanisms in all agreements, an overarching mechanism for all agreements should be introduced.
\end{abstract}

Keywords: IRBC Agreements, effectiveness, OECD due diligence, access to remedy

\section{Introduction}

The Ministry of Foreign Trade has identified thirteen risk sectors in connection with responsible business conduct in 2013 after research had been commissioned to a consultancy firm. ${ }^{1}$ At that time the government had

* Martijn Scheltema is Professor of Private law at Erasmus School of Law, Erasmus University Rotterdam.

1. Proceeds Second Chamber, House of Representatives 2013/14, 26485 , no. 187 , pp. 1 and 2 . announced it would implement legislation if these thirteen sectors would not conclude tripartite agreements on this topic with the government, NGOs and business before $2017 .^{2}$ The aim of this was to enhance implementation of responsible business conduct due diligence as included in the OECD Guidelines for multinational enterprises ${ }^{3}$ by business.

This has led to multi-stakeholder initiatives in several sectors, the International Responsible Business Conduct agreements, hereinafter referred to as IRBC agreements or agreements. However, not all thirteen sectors have concluded these agreements to date. These have been concluded in the Textile and Banking industry as well as in the Gold, Sustainable forestry, Food products, Insurance, Pension, Natural Stone (TruStone), Metals and Floriculture sectors. ${ }^{4}$

The IRBC agreements (and especially the Banking and Textile agreements) ${ }^{5}$ are internationally well known and seen as examples of the (innovative) Dutch approach of business and human rights (and more broadly responsible business conduct) issues. This contribution analyses whether the agreements live up to these expectations. This raises the issue of effectiveness of these agreements.

Thus, this contribution focuses on the effectiveness of these agreements and suggests some avenues for improvement. It takes a rather practical approach. Several challenges in connection with effectiveness have been identified in evaluations of the IRBC agreements. The challenges emerging from these evaluations are

2. However, it is still considering legislation next to the IRBC agreements. See the letter of the Minister of Foreign affairs to the Second Chamber of 3 April 2020, which can be accessed through www.tweedekamer.nl/ kamerstukken/brieven_regering/detail? id=2020Z06176\&did=2020D12968.

3. www.oecd.org/daf/inv/mne/48004323.pdf.

4. Next to these agreements the Coal, Vegetable Protein and Forestry agreements have been concluded, but these are not mentioned on the IRBC website anymore and apparently not considered to be IRBC agreements. See for the Vegetable Protein and Forestry agreements https://mvonederland.nl/sites/default/files/media/IMVO $\% 20$ Convenant\%20Plantaardige\%20Eiwitten_0.pdf and https:// bewustmethout.nl/wp-content/uploads/2018/05/ Origineel_Ondertekend_Convenant-Bevorderen-DuurzaamBosbeheer.pdf respectively. See for information on the Coal agreement www.government.nl/documents/reports/2020/09/28/final-reportdutch-coal-covenant-2020.

5. They are accessible through www.internationalrbc.org/agreements? sc_lang=en. 
used as a starting point for further analysis of the effectiveness of the IRBC agreements.

Although more agreements have been concluded, the Textile and Banking agreement will serve as an example of the governance and substance of the agreements. As the two first agreements which have been concluded, they are more or less representative of the majority of the agreements which have been concluded thereafter. ${ }^{6}$

\section{Effectiveness of Multi- stakeholder Initiatives in General}

Obviously, analysing effectiveness of the IRBC agreements raises the question how effectiveness (of multistakeholder initiatives) should be defined. Extensive research has been conducted on this issue but a shared and comprehensive definition has not emerged so far, which is further complicated because effectiveness issues may be approached from different angles. ${ }^{7}$ One may consider it from a legal perspective, amongst others looking at the specificity of standards, whether they are monitored and enforced and how dispute resolution systems are shaped. Impacts in practice of these initiatives, for example, in terms of cost of implementation, environmental consequences or improvement of the human rights situation, as well as their governance and stakeholder engagement may be other aspects to look at. For example, ISEAL, the global membership organisation for credible sustainability standards, ${ }^{8}$ incorporates many of these angles in their (meta-)standard for standard setting organisations in the agricultural sector. ${ }^{9}$ Beyond that, a specific assessment tool to evaluate the effectiveness of multi-stakeholder initiatives in the (business) human rights arena has been developed by MSI Integri-

6. It must be noted that the time for which the Banking agreement has been concluded has expired and the agreement is not prolonged. However, it is still a good example of the agreements in the financial sector.

7. See on this topic, e.g. R. Barkemeyer, L. Preuss and L. Lee, On the Effectiveness of Private Transnational Governance Regimes, Evaluating Corporate Sustainability Reporting According to the Global Reporting Initiative, Journal of World Business 2015 (vol. 50), p. 320; P. Pattberg and O. Widerberg, Transnational Multistakeholder Partnerships for Sustainable Development: Conditions for Success, Ambio 2016 (vol. 45), p. 47; M.W. Scheltema, Assessing Effectiveness of International Private Regulation in the CSR Arena, Richmond Journal of Global Law and Business 2014 (vol. 284); P. Verbruggen, ‘Private Regulation as a Form of New Governance in the EU', in: A. McCann e.a. (red.), When Private Actors Contribute to Public Interests, Den Haag: Eleven International Publishing 2014, pp. 228-31.

8. Seewww.isealalliance.org/.

9. See the ISEAL code of good practice for setting environmental and social standards 2014, to be accessed through www.isealalliance.org/ sites/default/files/resource/2017-11/

ISEAL_Standard_Setting_Code_v6_Dec_2014.pdf. ISEAL has also developed a tool to assess impact of such standards, see the ISEAL code of good practice for assessing impacts of social and environmental standard systems 2014, which can be accessed through www.isealalliance.org/sites/default/files/resource/2017-11/ ISEAL_Impacts_Code_v2_Dec_2014.pdf. ty. ${ }^{10}$ However, effectiveness can also be approached from other angles as a recent evaluation of the Dutch IRBC policies by the Ministry of Foreign affairs has shown, observing whether the objectives set by the government in connection with these agreements have been achieved. ${ }^{11}$ This has been observed by analysing the process of achieving outputs and/or observing the outputs themselves as well as the inputs needed to provide these outputs. ${ }^{12}$ This contribution does not aim to provide a substantive contribution to the ways in which effectiveness of multi-stakeholder initiatives such as the IRBC agreements may be analysed, ${ }^{13}$ but rather takes a practical approach. Several challenges are identified in evaluations of the IRBC agreements. The challenges in connection with effectiveness emerging from these evaluations are used as a starting point for further analysis of the effectiveness of the IRBC agreements. As the evaluations may provide insights into which challenges are considered to be salient by a broader audience, these may be a better starting point for effectiveness analysis of the IRBC agreements than diverging more general observations in academic literature on effectiveness of multi-stakeholder initiatives. Before effectiveness in the just indicated way is analysed, the governance, substance of the standards, collaboration in the agreements and dispute resolution will be briefly explained in the next paragraph. This may assist in digesting the effectiveness analysis.

\section{The IRBC Agreements}

\subsection{Governance}

The governance of the Textile and Banking agreements is comparable. ${ }^{14}$ Both have a steering group/committee which consists of representatives from government, industry organisations, participating business, members of those organisations, trade unions and civil society organisations as well as an independent chair. ${ }^{15}$ The

10. See the MSI evaluation tool 2017, which can be accessed through www.msi-integrity.org/wp-content/uploads/2017/11/

MSI_Evaluation_Tool_2017.pdf. See on this in connection with land rights, Addressing Land Governance in International Responsible Business Conduct Agreements 2018, p. 58.

11. IOB Evaluation, Mind the governance gap, map the chain, Evaluation of the Dutch government's policy on international responsible business conduct (2012-2018) (hereinafter IOB Report), accessible through www.iob-evaluatie.nl/publicaties/evaluaties/2019/09/01/433\%E2\%80\%93-iob-\%E2\%80\%93-evaluation-of-the-dutchgovernments-policy-on-international-responsible-businessconduct-2012-2018-\%E2\%80\%93-mind-the-governance-gap-mapthe-chain.

12. IOB Report, p. 52

13. See on this e.g. Scheltema.

14. They may be accessed through www.internationalrbc.org/agreements? sc_lang=en. Industry associations instead of individual companies are signatories in the forestry and food agreements.

15. See e.g. Art. 5.1.2 of the Textile agreement, Arts. 13.1.c and 13.1.d of the Banking agreement, Arts. 10.1.3 and 10.1.7 of the Insurance agreement, Arts. 19.3 and 19.4 of the Pension Fund agreement and Arts. 7.1 and 7.2 of the Gold agreement. See also Arts. 6.17-6.26 of the Metals agreement and Art. 10.2 of the TruStone agreement. See also IOB Report, p. 58 
steering group decides by consensus in principle and lacks consensus by majority vote. ${ }^{16}$ It has to manage the agreement 'day-by-day' and the steering group of the Textile agreement has the mandate to take supplementary and corrective measures. ${ }^{17}$ Furthermore, it decides on new projects, initiatives, collaboration with other parties and enters into or terminates projects. ${ }^{18}$

Beyond this, the agreements include the establishment of a secretariat which is administered by the Dutch Social Economic Council (SER), which is an independent body funded by the government. ${ }^{19}$ The secretariat also engages and pays experts if they are required to develop the agreements in practice in collaboration with the signatories. Furthermore, it bears the cost of administering the agreements. ${ }^{20}$ The SER has appointed a director in charge of all agreements.

\subsection{Substance of the Standards}

\subsubsection{Introduction}

The Textile and Banking agreements rely on the United Nations Guiding Principles on Business and Human Rights (UNGP), ${ }^{21}$ the OECD Guidelines for Multinational Enterprises (OECD Guidelines) ${ }^{22}$ and sector-specific guidance such as in the Textile and footwear sectors. ${ }^{23}$ For example, Article 1.1 of the Textile agreement refers to human rights due diligence as adopted in UNGP 17 and elaborated in UNGP 18-21 as well as in Section IV.5 of the OECD Guidelines and the OECD Guidance in the Textile and footwear sectors. ${ }^{24}$ Both agreements implement the same basic features: (i) a due diligence requirement that builds on the UNGP and OECD Guidelines for Multinational Enterprises, (ii) access to remedy (in different formats) if an adhering company causes or contributes to human rights or environmental violations as well as the implementation of

16. See e.g. Art. 5.1.4 of the Textile agreement. Pursuant to Art. 13.1.e of the Banking agreement, Art. 10.1 .5 of the Insurance agreement, Art. 19.6 of the Pension Fund agreement, Art. 7.3 of the Gold agreement and Art. 10.6 of the TruStone agreement decisions need to be taken by consensus and no majority decision-making is allowed.

17. Art. 5.1.4 of the Textile agreement, Art. 13.1.h of the Banking agreement, Art. 10.1 .6 of the Insurance agreement, Art. 19.2 of the Pension Fund agreement, Art. 7.5 of the Gold agreement and Art. 6.25 of the Metals agreement.

18. Art. 5.1.6 of the Textile agreement, Art. 13.1.h of the Banking agreement, Art. 10.1 .6 of the Insurance agreement, Art. 7.6 of the Gold agreement, Art. 6.25 of the Metals agreement and Art. 10.8 of the TruStone agreement.

19. Art. 5.2 of the Textile agreement, Arts. 13.1.i and 13.1.k of the Banking agreement, Art. 19.7 of the Pension Fund agreement and Art. 7.7 of the Gold agreement. Arts. 6.27-6.31 of the Metals agreement and Art. $10.13 \mathrm{ff}$ of the TruStone agreement do not clarify whether the SER is involved in the secretariat, but allow this.

20. Proceeds Second Chamber 2017/18, 26 485, no. 253, p. 2

21. Which can be accessed through www.ohchr.org/Documents/ Publications/GuidingPrinciplesBusinessHR_EN.pdf.

22. www.oecd.org/daf/inv/mne/48004323.pdf.

23. OECD Due Diligence Guidance on responsible supply chains in the Textile and footwear sector, which can be accessed through https:// www.oecd-ilibrary.org/governance/oecd-due-diligence-guidance-forresponsible-supply-chains-in-the-garment-and-footwearsector_9789264290587-en.

24. This type of due diligence will hereinafter be referred to as 'OECD due diligence'.

dispute resolution remedies and (iii) a reporting requirement on due diligence (policies) and access to remedy. ${ }^{25}$ (i) and (iii) will be elaborated in the next paragraphs, to provide some insight into the functioning of the agreements. (ii) is part of the effectiveness analysis and will be discussed in the subparagraph on access to remedy.

The Textile agreement is a binding agreement which is enforceable in law. This is, amongst others, reflected in its binding dispute resolution mechanism. ${ }^{26}$ Conversely, the Banking agreement declares the agreement is not enforceable in law. ${ }^{27}$

\subsubsection{Due Diligence}

As has been elaborated hereinabove, both agreements include a comparable due diligence requirement. The Textile agreement includes elaborate provisions on due diligence and requires the adhering parties to implement human rights due diligence and prepare and present an annual action plan as part of their due diligence process. ${ }^{28}$ Nine specific themes are identified in the agreement on which the due diligence process focuses. ${ }^{29}$ This action plan includes (i) the insights they have gained into their production or supply chain through the due diligence process and the possible impacts in their supply chain in terms of the UNGP and the OECD Guidelines, (ii) how their own purchasing process contributes to potential (risks of) adverse impacts and measures to be taken to mitigate them, (iii) the policy and the measures they pursue with regard to the nine themes prioritised by the parties and how they will participate in the collective projects and (iv) setting quantitative and qualitative objectives in terms of improvements for the duration of the agreement, broken down into objectives after three and five years. ${ }^{30}$ Next to this they have to implement specific measures regarding the nine themes identified in the agreement, for example, by implementing obligations in their supply chain contracts in connection with several of these themes. ${ }^{31}$

The Banking agreement pertains to project finance and corporate lending and thus does not yet relate to asset management. ${ }^{32}$ It requires the adhering banks to develop a public policy statement declaring it respects human rights. This statement should include (i) a commitment to respect human rights, in conformity with the OECD Guidelines and the UNGP, which should be reflected in policies and procedures, including the application of the International Finance Corporation Performance Standards or Equator Principles in the case of project finance and embed it throughout the bank, (ii) information on

31. Appendix 1 of the Textile agreement. Art. 4.2 envisages a role for the government in connection with this too as it has to provide support as to the meaning of due diligence for options and constraints in mutual agreements and which means may assist in adapting contractual mechanisms.

32. Art. 2.1 of the Banking agreement. 
activities that the individual bank will not finance or invest in, (iii) a human rights due diligence procedure, (iv) sector and/or theme policies outlining human rights standards and parameters under which the bank conducts business in sectors that are deemed high-risk sectors according to the bank or assessed as such on the basis of the information in the matrix/database developed by the adhering parties. ${ }^{33}$

The adhering banks had committed to implement human rights due diligence in conformity with the OECD Guidelines and UNGP within two years after becoming a signatory, which should explicitly acknowledge the necessity to assess human rights risks to others than the bank itself. ${ }^{34}$ However, human rights due diligence could vary in complexity with the size of the business enterprise of the banks' clients, the risk of severe human rights impacts, and the nature and context of its operations. Human rights due diligence should include (i) ascertaining that the client processes involve meaningful and effective consultation by their clients with potentially affected groups and other relevant stakeholders, (ii) requiring clients and prospective clients to provide information needed for identifying and assessing actual and potential human rights impacts related to the client or the transaction at hand, (iii) requiring Free, Prior and Informed Consent (FPIC) (compliant with the International Finance Corporation Performance Standards or the Voluntary Guidelines on the Responsible Governance of Tenure (VGGT)) in project finance and actively promote this in connection with corporate loans including meaningful and effective consultations with potentially affected groups and other relevant stakeholders (if applicable compliant with the IFC PS or VGGT) if a fair possibility of land rights violations exists. ${ }^{35}$ The banks should integrate findings from impact assessments across their internal functions and processes, although the engagement process with clients should be time and result oriented with a focus on the most severe impacts. ${ }^{36}$ Beyond that, the adhering banks have jointly carried out value chain mapping exercises of high-risk sectors which are material to banks. ${ }^{37}$

\subsubsection{Reporting}

In terms of reporting the signatories to the Textile agreement acknowledge the importance of public communication as described in the OECD Guidelines. The specific reporting requirements (including those of existing initiatives) were not set in the agreement itself but should be agreed upon by the steering group after one year. In the third year of the agreement the adhering enterprises should report publicly individually. ${ }^{38}$

The signatories to the Banking agreement had also committed to start working towards (i) reporting in line with

33. Art. 3.1 of the Banking agreement. See Art. 5.1 of the agreement for the matrix/database.

34. Arts. 4.1 and 4.2 of the Banking agreement.

35. Art. 4.3.a of the Banking agreement.

36. Art. 4.3.b of the Banking agreement. That said, this article describes what client engagement ideally looks like.

37. Art. 5.2 of the Banking agreement.

38. Art. 1.1 of the Textile agreement. or equivalent to the UN Guiding Principles Reporting Framework, (ii) publishing detailed information on exposure to economic sectors, in accordance with the Dutch Association of Banks (NVB) Reference for Reporting on Loans, ${ }^{39}$ or, if they prefer to do so, a list of enterprises the bank has a credit or investment relationship with and (iii) a published list of the bank's investment universe for asset management using individual listed shares for Dutch clients at least as of 31 December of each year, or a published list of listed companies excluded from such an investment universe on the basis of Corporate Social Responsibility criteria. ${ }^{40}$

\subsection{Collaborative Action and Continuous Learning}

The agreements are not only meant to impose obligations on signatories but also as a continuous and collaborative learning process. Signatories to the agreements collaboratively try to improve the performance by discussing topics amongst each other and by engaging with experts. For example, both the Textile and the Banking agreements envisage databases with countries and/or sectors and/or production facilities to assist signatories to improve their risk assessments and due diligence. ${ }^{41}$ The Textile sector currently has published an aggregated list with approximately 4,300 production facilities and the secretariat assists in connecting external complainants with signatories sourcing from these production facilities. ${ }^{42}$ The Banking agreement has conducted collaborative value chain mapping in the cocoa, palm oil, gold and oil and gas sectors. ${ }^{43}$ The signatories to the Textile and Banking agreements also have collaborated to move to payment of living wages. ${ }^{44}$

\subsection{Dispute Resolution}

Dispute resolution options vary along the Textile and Banking agreements. In this paragraph only dispute resolution between the parties to the agreements will be discussed. However, the Textile agreement includes a complaint mechanism for external parties against business signatories. This mechanism will be explained and discussed in the paragraph on access to remedy.

The Textile agreement avails an independent and binding dispute mechanism. If the secretariat of the agreement has made a signatory company to implement certain improvements (to its action plan) but it fails to

39. See Art. 6.1 of the Banking agreement.

40. Art. 6.4 of the Banking agreement.

41. And Art. 5.1 of the Banking agreement

42. Proceeds Second Chamber 2017/18, 33 625, no. 246, p. 3. See also IOB Report, pp. 75 and 77. In case of issues at a production location the secretariat of the agreement may act as a broker between complaints and individual signatories. See IOB Report, p. 77 and for the procedure www.imvoconvenanten.nl/en/Textiles-textile/agreement/ complaints. Some frontrunners even disclose their individual suppliers. See IOB Report, p. 75 and the Open Apparel Registry can be found at https://openapparel.org/.

43. Art. 5.2 of the Banking agreement. The reports can be accessed through www.imvoconvenanten.nl/en/banking/about-this-agreement/ publicaties.

44. See pp. 32-34 of the Textile agreement and Art. 8 of the Banking agreement. See also Proceeds Second Chamber 2017/18, 33 625, no. 246, p. 4. 
do so, the secretariat may $\log$ a dispute at the binding independent dispute resolution mechanism of the agreement (after permission of the steering committee of the agreement). ${ }^{45}$ This mechanism will lead to a binding decision on the issue which is published. ${ }^{46}$ If the adhering company refuses to implement the decision of the binding dispute resolution body the case is referred to arbitration at the Dutch Arbitration institute. ${ }^{47}$ It also involves the option to 'blacklist' a supplier from whom signatories to the agreement are no longer allowed to source. ${ }^{48}$ The Banking agreement includes a dispute resolution mechanism, not deploying an independent dispute resolution committee. ${ }^{49}$ The disputing parties should first try to solve the issue amicably and if this is unsuccessful the steering committee will deal with the issue after it has been informed about it. ${ }^{50}$ The steering committee will initiate a dialogue between the parties and may also invite third parties to become part of this dialogue as well as call experts agreed upon by the parties. ${ }^{51}$ The steering committee should do its utmost to reach a unanimous decision. ${ }^{52}$ The steering committee will advise disputing parties and recommend timebound follow-up steps. Parties will in principle have 6 months to follow up. ${ }^{53}$ Three weeks after this period the steering committee will take a final decision (if it is able to decide on this unanimously) and communicate this to the disputing parties. ${ }^{54}$ The decision is binding on the parties; however, it is not enforceable in law. ${ }^{55}$ This decision is made public, unless the steering committee decides otherwise (in part). ${ }^{56}$ The disputing parties are expected to follow up the recommendations of the steering committee. ${ }^{57}$ If a disputing party does not, the steer-

45. The author of this contribution is the independent chair of this mechanism.

46. To date two cases have been decided. See for these decisions www.imvoconvenanten.nl/en/Textiles-textile/agreement/complaints.

47. See Art. 1.3 of the Textile agreement and for the procedural rules www.internationalrbc.org/Textiles-textile/agreement/method/ complaints?sc_lang=en.

48. See on this feature e.g. A. Duval and E. Partiti, The UN Guiding Principles on Business Human Rights in (National) Action: The Dutch Agreement on Sustainable Textile and Textile, in: F. Ambtenbrink et al. (eds.), Netherlands Yearbook of International Law 2017: Shifting Forms and Levels of Cooperation in International Economic Law: Structural Developments in Trade, Investment and Financial Regulation, Berlin: Springer 2018, p. 402

49. Art. 13.3 of the Banking agreement.

50. Art. 13.3.b of the Banking agreement. In such case the adhering bank and the Dutch Association of Banks should also be informed pursuant to Art. 13.3.c of the Banking agreement. Pursuant to Art. 13.3.d the disputing parties will have no vote in the steering committee. See also Arts. 10.3.1 and 10.3.2 of the Insurance agreement.

51. Arts. 13.3.g and 13.3.h of the Banking agreement. See also Arts. 10.3.5 and 10.3.6 of the Insurance agreement, which however does not include the option to engage experts or third parties.

52. Art. 13.3.h of the Banking agreement. See also Art. 10.3.7 of the Insurance agreement. If this is not possible an external mediator may be engaged pursuant to Art. 10.3.7 of the Insurance agreement.

53. Art. 13.3.i of the Banking agreement.

54. Arts. 13.3.j, 13.3.k and 13.3.m of the Banking agreement.

55. Art. 13.3.I of the Banking agreement.

56. Art. 13.3.n of the Banking agreement. See also Art. 10.3.11 of the Insurance agreement.

57. Art. 13.3.p of the Banking agreement. See also Art. 10.3.9 of the Insurance agreement. ing committee will organise a meeting with this party in order to incentivise it to follow up and may eventually expel this party if it still refuses to follow up. ${ }^{58}$

\section{Effectiveness}

\subsection{Introduction}

The different evaluations of the IRBC agreements by and large identify four themes in connection with their effectiveness: (i) uptake, leverage and collaboration, (ii) implementation of OECD due diligence including monitoring, (iii) access to remedy and (iv) the role of the government. I will discuss effectiveness of the agreements along the lines of the first three themes in the next paragraphs. The fourth theme, although relevant, ${ }^{59}$ is not included as it is connected to the government and the focus in this contribution is on implementation of OECD due diligence by and material changes in behaviour of business signatories to the agreements. ${ }^{60}$

\subsection{Uptake, Leverage and Collaboration}

\subsubsection{Uptake and Leverage}

As has emerged from the evaluation of the Department of Policy and Operations Evaluation of the Ministry of Foreign Affairs (IOB), the objective of ten IRBC agreements in the thirteen risk sectors by the end of 2016 has not been achieved. ${ }^{61}$ Several causes were found for this delay, amongst others: the nature of a learning process, the time needed to build trust between diverging stakeholders, limited knowledge on due diligence, new demands in late stages, extensive discussions on governance and enforcement as well as the large number of actors. ${ }^{62}$ It is observed that an industry association may assist in achieving higher market participation, as membership of many market actors may incentivise uptake. ${ }^{63}$ For example, in the forestry, vegetable protein, gold, food and insurance about $90 \%$ of market actors is signatory. ${ }^{64}$ Being a member of the industry association in the insurance sector even implies one should sign the insurance agreement. ${ }^{65}$ However, as the IRBC agreements

58. Art. 13.3.q of the Banking agreement. If a party is expelled this is made public pursuant to Art. 13.3.r of the Banking agreement. See also Art. 10.3.11 of the Insurance agreement.

59. See on this e.g. IOB Report, pp. 59-68 and 76.

60. Furthermore, transparency of business performance and discussions within the agreements are seen as an effectiveness indicator. In my view this is relevant, but rather as a tool to assess whether agreements are effective than an effectiveness criterion as such.

61. IOB Report, pp. 53-5. Currently (2020) ten agreements have been concluded and three others are being explored (not necessarily in identified risk sectors). Cf. IOB Report, p. 54. One agreement (banking sector) has terminated at the end of 2019.

62. IOB Report, p. 55.

63. IOB Report, pp. 57 and 58.

64. IOB Report, p. 57. However, it is unclear how many companies are bound by the food agreement because no individual company has committed to it. See Evaluation of the Dutch RBC Agreements 2014-2020, Amsterdam 2020, pp. 51 and 54-7, which can be accessed at www.kit.nl/publication/evaluation-of-the-dutch-rbcagreements-2014-2020/.

65. IOB Report, p. 58. 
are voluntary and their effectiveness is highly dependent on (proactive) collaboration between signatories, a high market share may not be a sign of effectiveness per se. Thus, it may not be a big issue that most agreements lack a focus on expanding market share. ${ }^{66}$ Proactive collaboration may benefit most from proactive participants. If agreements are concluded because of a desire of the government but (market) participants feel this is unnecessary because other initiatives exist ${ }^{67}$ or are not inclined to meaningfully collaborate, this may hamper meaningful outcomes of the agreements. Furthermore, concluding agreements in niches of markets may work well in terms of developing new and proactive approaches which have not yet gathered support from larger market actors. Thus, these agreements may develop proactive approaches which may mature in the market at large in the future. ${ }^{68}$ IRBC agreements may be more fit to develop proactive best practices and this may be easier if the market at large does not have to participate. Thus, large uptake is not necessarily a sign of effectiveness.

However, a small number of signatories may imply the leverage of such an agreement is limited. In the midterm evaluation of the Textile agreement it is observed the desired $80 \%$ adherence in the market can only be achieved by including larger foreign companies. ${ }^{69}$ Thus, eventually a larger uptake (also outside the Netherlands) seems helpful to increase the impact of the agreements. ${ }^{70}$ That said, leverage may be increased by (effective) collaboration between IRBC agreements and this may benefit leverage of IRBC agreements with more limited uptake. Beyond this, agreements may also collaborate with or use other multi-stakeholder initiatives (e.g. local or certification initiatives) to support implementation of the agreements and to increase leverage. Collaboration with other multi-stakeholder initiatives is sought in the Textile agreement.

\subsubsection{Collaboration}

In terms of collaboration within the IRBC agreements the IOB evaluation has observed the agreements have resulted in enhanced communication and knowledge sharing between business and NGOs, increased awareness of IRBC risks and regulations with business, increased transparency as far as allowed by competition law and within the commercial interest boundaries as well as improved due diligence reporting in three agreements. ${ }^{71}$ The evaluation of the Banking agreement by

66. As is observed in the IOB Report, pp. 74 and 78

67. See on this e.g. KIT, Evaluation of the Dutch RBC Agreements, pp. 36 and 39-41, which report also observes pre-existing initiatives may incentivise collaboration in the RBC agreements.

68. It is observed that legislation directed at incentivising participation in these agreements may support collaboration and uptake of such proactive approaches. See SER, Samen naar duurzame ketenimpact, Den Haag 2020, p. 26, which can be accessed at www.ser.nl/-/media/ser/ downloads/adviezen/2020/imvo-duurzame-ketenimpact.pdf? $\mathrm{l}=\mathrm{n} \mid$ \&hash=F8493405C804DAD3E96D95B5DF5C0AA8

69. See pp. 4-8 of the evaluation.

70. Cf. KIT, Evaluation of the Dutch RBC Agreements, pp. 62-8.

71. IOB Report, p. 74. See also KIT, Evaluation of the Dutch RBC Agreements, pp. 36 and 39. Especially the first steps of the due diligence process have improved. See ibid, p. 70; SER, Samen naar duurzame the supervisory committee has revealed the (published) work of several working groups has benefitted not only signatories but external parties as well. ${ }^{72}$

Beyond this, mutual learning was observed not only within the agreements but also between the agreements (e.g. in connection with child labour and living wage) in which the independent chairs of the agreements played an important role in sharing experiences. ${ }^{73}$ This is also explicitly provided for by some agreements. For example, Sections 5.38 and 5.39 of the Metals agreement explicitly envisage collaboration with other agreements.

However, this type of collaboration may be broadened and deepened in order to enhance effectiveness. ${ }^{74} \mathrm{~A}$ way to incentivise and institutionalise collaboration amongst agreements may be to use the UN Sustainable Development Goals (SDGs) to identify overarching topics participants in all agreements could work on collectively. This may enhance leverage and performance of the individual agreements as well as incentivise continuous learning and training of the signatories to all agreements. Such SDGs may include living wages, child labour and decent work on which collaboration between the agreements has already been established. The advantage of using the SDGs is that they provide a clear agenda for collaboration (see also SDG 17) and (performance) indicators for the achievement of the goals. For example, it may be helpful (which is also expressed by SDG 17) to involve (representatives of) affected groups in this collaboration in order to better understand the effects of the initiatives developed 'on the ground'. To date collaboration within the agreements mainly involves Dutch actors. Beyond this, the SDGs have a more positive connotation than the 'do no harm' agenda connected to human rights issues and may thus incentivise initiatives on these topics.

In terms of institutionalising this collaboration and not making it dependent on individual chairs an overarching body of experts may be established. It could identify, guide and supervise such common topics which are addressed in the different agreements and incentivise collaboration on those topics as well as collaborative learning in order to increase leverage. For example, if living wage is a topic the Textile agreement is working on, this may be shaped around collaborative sourcing from specific production locations which only work for companies implementing high RBC standards. The aim

ketenimpact, p. 25. However, the midterm evaluation of the Textile agreement reveals the roles and responsibilities in the collaborative model should be better defined. See pp. 4-8 of the midterm evaluation of the Textile agreement.

72. See on this www.imvoconvenanten.nl/en/banking/about-thisagreement/publicaties. Cf. KIT, Evaluation of the Dutch RBC Agreements, pp. 106, 107 and 115. However, a limited participation and uptake of companies in and of collaborative projects is observed. See KIT, Evaluation of the Dutch RBC Agreements, pp. 112 and 113.

73. IOB Report, p. 75.

74. See also SER Voortgangsrapportage IMVO Convenanten, Samen op weg naar verantwoorde ketens, Report July 2018, para. 6 (Dutch only). Cf. Addressing Land Governance in International Responsible Business Conduct Agreements 2018, p. 65, which report suggests a role for the SER and Dutch NCP. 
of this collective sourcing would be to create a business model for the production facility to produce responsibly. In creating such a business model banks and institutional investors may play a role, for example, by providing loans or guarantees (also to other actors in the supply chain). This may create additional leverage to convince production facility owners and host governments (as it is an economic business model) to engage. The overarching body may assist in designing the way in which the collaboration should be shaped and where collaboration is feasible. This body may also assess whether collaboration with other (local) multi-stakeholder initiatives may be feasible.

One may argue SER may perform this role instead of such an overarching body of experts as it, to date, administers most agreements. However, the SER secretariat also performs a supervisory role in connection with monitoring compliance with some agreements and does not administer all agreements. Thus, this may complicate the overarching function just described. Beyond that, a body of experts may also include or engage (foreign) experts or (local) multi-stakeholder initiatives with expertise not available within the SER secretariat to identify or manage such overarching themes. $^{75}$

\subsection{Implementation of OECD Due Diligence and the Need for Effective Monitoring of It}

\subsubsection{Implementation of OECD Due Diligence in a Coherent Manner}

Most agreements, as has been elaborated in the foregoing, aim to support and incentivise uptake and implementation of OECD due diligence. However, many focus on specific areas of due diligence mainly in connection with human rights and less so in connection with, for example, climate. ${ }^{76}$ Some business actors, for example, in the banking sector, argue this is sufficiently covered by other initiatives. ${ }^{77}$ Furthermore, the forestry and vegetable protein seem to focus on enhancing sustainable business ('do good') instead of focusing on the negative externalities, such as human rights abuses ('do no harm'). ${ }^{78}$ All agreements seem to focus on issues not yet sufficiently addressed by laws, regulations and sector initiatives. ${ }^{79}$ By and large, human and labour rights, as well as the environment are considered to be such issues. Within these issues specific attention is given to living wage, gender discrimination, child labour, corruption and animal welfare. ${ }^{80}$ It is observed the Insurance and Pension Fund agreements include a balanced mix of specialised NGOs on all these topics. Several other agreements have a less balanced mix of representatives. For example, the Textile agreement does not

75. That said, the SER has consulted and engaged foreign experts in the agreement process

76. IOB Report, p. 59.

77. Ibid. This is also observed in connection with the focus of the forestry agreement. See IOB Report, p. 60

78. IOB Report, p. 60.

79. Ibid.

80. Ibid, pp. 60 and 61 include specialised environmental NGOs. ${ }^{81}$ Effectiveness may be enhanced by such a balanced mix. Furthermore, even where agreements are aiming at implementing OECD due diligence, not all components seem to be included. For example, the agreements do not seem to include decisions to either stay in or source from a specific country or the ability to shift practices if the situation in countries changes. Beyond this, some agreements rely on risk assessments on a broader country level, but these will not directly or necessarily reveal issues at the factory level. Furthermore, issues regarding outsourcing by suppliers are often not addressed in due diligence requirements. Responsible exits (disengagement with supplier in a responsible manner) are not covered in the guidance for signatories either, but highly important, also in these Covid-19 times. Recent cancellation in orders of Textile which had already been produced is an example of this. Finally, it has been argued that the IRBC agreements have not implemented all relevant frameworks in connection with human rights compliance. For example, relevant frameworks on land rights seem not to be explicitly addressed in most agreements. ${ }^{82}$ That said, these issues may be included in OECD due diligence and thus could be addressed through the agreements. Finally, it is observed that the prioritisation required by the OECD Guidelines is difficult to put into practice. ${ }^{83}$

In terms of enabling uptake, collaboration between agreements and effective monitoring it seems most effective if all agreements would adhere to the OECD due diligence standard and implement it in a comparable manner (also in connection with prioritisation), because this standard is likely to be implemented in upcoming EU legislation and is implemented through existing legislation in some EU member states. ${ }^{84}$ This would also facilitate collaboration within and between agreements and the agreements' secretariats and would enhance effectiveness. As far as collaboration within the agreements is concerned the IOB evaluation confirms sticking to OECD due diligence may be most effective. NGOs in the Banking and Insurance agreements have tried to reach agreement on issues which (arguably) go beyond the OECD Guidelines, which gave the govern-

81. Ibid, pp. 61 and 62 . Which may be explained by the specific focus of some of the agreements. See IOB Report, p. 62

82. See Addressing Land Governance in International Responsible Business Conduct Agreements 2018, pp. 64 and 65. For example, it may be helpful to gather and provide information on land rights violations and environmental impacts in different countries. See Addressing Land Governance in International Responsible Business Conduct Agreements 2018 , pp. 21, 22 and 61. However, some newer agreements such as the Metals and Floriculture agreements do include specific reference to land rights.

83. See pp. 4-8 of the evaluation.

84. See for the proposal on EU legislation www.business-humanrights.org/ en/eu-commissioner-for-justice-commits-to-legislation-on-mandatorydue-diligence-for-companies. See on existing legislation in EU member states L. Smit et al., Study on due diligence requirements through the supply chain, Part III, Country Reports, accessible through https:// op.europa.eu/en/publication-detail/-/publication/0268dfcf-4c85-11eab8b7-01aa75ed71a1/language-en. 
ment a role of mediator. ${ }^{85}$ In response the government clarified expectations and proposed a more leading role, but this was not accepted by the signatories. ${ }^{86}$ Thus, this has hampered collaboration within these agreements. Conversely, the Textile agreement did not cover issues beyond the OECD Guidelines (except for animal welfare) and participants were able to reach consensus on principles and expectations much sooner. ${ }^{87}$

\subsubsection{Monitoring}

However, one may question whether the agreements bring about material changes in behaviour of signatory companies regarding the implementation and undertaking of OECD due diligence. This is relevant as the agreements are not aiming at 'ticking the box' exercises but on material changes on the ground where impact arises. ${ }^{88}$ Obviously, this change of behaviour does not depend exclusively on which components of OECD due diligence are included in the agreements or how OECD due diligence is implemented, but also on how implementation and undertaking of OECD due diligence is monitored. The midterm evaluation of the Textile agreement has shown monitoring by the secretariat, as has been developed in the Textile agreement, is appreciated by its signatories and its guidance and tools assist companies in performing better. ${ }^{89}$

The way monitoring is shaped in the Textile agreement is the most elaborate of all agreements. Business signatories have to provide confidential information to the secretariat. In the first year they have to provide information on the countries where their products are manufactured, the production locations and production processes concerned and turnover, in the second year the raw materials used in their collections and the risks identified in the use of these raw materials and in the third year the subsequent links in their production or supply chain. ${ }^{90}$ From the second year onwards they also have to provide a report on the results of the previous year's plan, in which they account for the progress made. The secretariat uses this information to provide information on the benefit of and need for collective projects and an annual aggregated report and to establish an annual benchmark for each theme, showing their progress and the targets to be met. ${ }^{91}$ It is suggested it could also develop databases on best practices in the sector. ${ }^{92}$ Beyond that, parties have to establish a list to clarify the extent to which enterprises' participation in existing initiatives (e.g. FWF, BSCI, ETI, SAC, ZDHC) complies with particular points in the arrange-

85. IOB Report, p. 71.

86. Ibid.

87. Ibid

88. See on impact on the ground IOB Report, pp. 168 and 169.

89. To be found at www.imvoconvenanten.nl/-/media/imvo/files/kleding/ 2019-textile-midterm.pdf?

$\mathrm{la}=$ en\&hash=081285CF1B445862CAB4F8F76C9C686F, pp. 4-8. Cf. KIT, Evaluation of the Dutch RBC Agreements, pp. 70, 77, 82 and 92. See also Duval and Partiti, p. 397.

90. Art. 1.1 of the Textile agreement.

91. Ibid.

92. Duval and Partiti, p. 399. ments made and to develop tools to assist participating enterprises in completing their due diligence process in line with the structure of the OECD's Due Diligence Guidance for Responsible Supply Chains in the Textile and Footwear Sector, whereas specific guidelines will be developed for small and medium-sized enterprises. ${ }^{93}$ The secretariat has a monitoring and assessment function in this. It provides feedback to participating enterprises in preparing their action plan, organises training and support for enterprises in the area of due diligence, assists parties to develop tools and activities which will help participating enterprises to conduct their due diligence and assesses the quality and the annual progress of the action plans which these enterprises prepare as part of their due diligence. ${ }^{94}$ The secretariat will also compare the enterprises' quantitative objectives in respect of the nine themes, ${ }^{95}$ based on the action plans received. ${ }^{96}$ It is suggested a focus on the companies between the frontrunners and laggards, including SMEs, may increase implementation in business strategy. ${ }^{97}$

It is likely this type of monitoring leads to material changes in behaviour of business signatories and is thus quite effective, as also follows from the midterm evaluation of the Textile agreement which observes the logic of the strategies of due diligence as described in the theory of change is confirmed. ${ }^{98}$ As has been elaborated in Section 3.3 it also has incentivised collaboration between the parties to the agreement in order to address structural challenges such as living wages.

\subsubsection{Need for an Escalation Mechanism}

In my opinion the effectiveness of monitoring by the secretariat in the Textile agreement is strengthened by the escalation option to binding dispute resolution, as has been elaborated in Section 3.4. This enables resolution of issues in connection with OECD due diligence which the secretariat and business signatory are not able to solve themselves. This option prevents a 'deadlock' where the secretariat requires certain actions from the company which refuses to implement them. Without an (binding) escalation option it is likely this issue will not be resolved and the desired actions are not implement-

93. Art. 1.1 of the Textile agreement.

94. Art. 1.2 of the Textile agreement. The criteria for assessing the action plans are implemented in Appendix 4. They adopt a reasonable and fair approach to the specific circumstances of the individual enterprise concerned and a careful prioritisation of activities, based on the following questions: (i) what is the likelihood of an adverse impact, (ii) how severe is that impact in terms of its extent, the number of people affected and the irreversibility of the consequences, (iii) specific ambitions and improvements and quantitative and qualitative objectives for improving the baseline position of the enterprise, at least with regard to the 'salient risks' encountered in the due diligence process and (iv) the extent to which a demonstrable continuous and improvement process exists.

95. See Section 3.2.2 above.

96. Art. 1.2 of the Textile agreement.

97. IOB Report, p. 78.

98. See pp. 4-8 of the evaluation, accessible at www.imvoconvenanten.nl/-/media/imvo/files/kleding/2019-textilemidterm.pdf?la=en\&hash=081285CF1B445862CAB4F8F76C9C686F. Cf. KIT, Evaluation of the Dutch RBC Agreements, pp. 70, 76, 77, 80, 92, 103, 104, 107 and 108. 
ed. Obviously, the business signatory may be expelled from the agreement by the steering committee in theory (an option all agreements avail over), but this has not happened to date and is unlikely to happen every time a dispute arises between the secretariat and a business signatory. Therefore, the latter thread is less likely to bring about material changes in behaviour of business signatories. An escalation mechanism is especially important because the Textile agreement by and large builds on the UNGP and OECD Guidelines for Multinational Enterprises as well as supporting guidance, which are not intended as binding instruments. Thus, the norms set by these frameworks may as such be not specific enough to be enforceable as a legal norm. That said, legislation often includes open norms and the judiciary has been capable of adapting and applying these norms in specific instances. Therefore, the openness of the norms as such may not be an impediment as long as (binding) dispute resolution mechanisms including an independent (third-party) panel are available to clarify the meaning of these norms in specific instances. Thus, the Textile agreement mechanism has the potential to transpose these more general and open norms included in this agreement to norms which set obligations originating from the agreement in specific cases. Lacking such a mechanism the norms included in the agreement may remain too open to infer specific obligations of the signatories from it in specific cases. This may also arouse discussion between the secretariat and business signatories.

\subsubsection{Cost of Monitoring and Escalation Mechanism}

The foregoing has revealed monitoring by the secretariat of the Textile agreement requires a lot of effort and capacity and, thus, is costly. ${ }^{99}$ To a lesser extent this is also true for the dispute resolution mechanism. Thus, effectiveness is connected with available funding and staff, which differs amongst the agreements. ${ }^{100}$ The Dutch government incurs the majority of these costs ${ }^{101}$ of the secretariat and dispute resolution mechanism of the Textile agreement and it is questionable whether it will fund other agreements if these would desire a comparable type of monitoring. Furthermore, it may be that business signatories are not prepared to cover these expenses. ${ }^{102}$ That said, the secretariat of the Textile agreement has developed a lot of useful tools which may also be deployed in other sectors, sometimes with slight adaptations. Thus, if such monitoring is undertaken by secretariats of other agreements, it is likely these secretariats do not have to reinvent the wheel and may build on expertise from the Textile agreement. This may reduce cost considerably. To enhance the collaboration between secretariats and dissemination of expertise it may be helpful to have the SER host all secretariats with a monitoring function, as it currently hosts many of them including the Textile agreement secretariat. This

99. Cf. KIT, Evaluation of the Dutch RBC Agreements, p. 120 100. IOB Report, p. 70. Cf. ibid, p. 119.

101. See KIT, Evaluation of the Dutch RBC Agreements, p. 121.

102. Cf. ibid, p. 119 may also enable employees of SER to function within more secretariats which may also reduce cost and enhance the optimal use of expertise.

\subsubsection{Other Types of Supervision Less Effective}

The types of monitoring implemented in other agreements, either by a monitoring committee or steering committee, seem less effective in terms of bringing about material changes in the behaviour of business signatories. ${ }^{103}$ For example, in the Banking agreement adhering banks had to report to the secretariat on the implementation of the commitments in connection with their public policy and human rights due diligence, more specifically meaningful information on the proceedings and results of human rights due diligence and ultimately directed towards a practically feasible combination of qualitative and quantitative information on the basis of priorities, including the most severe human rights impacts identified. ${ }^{104}$ With respect to these impacts they should communicate (i) the efforts made to prevent and mitigate these adverse human rights impacts, striving to include the use and frequency of screening processes, stages of engagement, deadlines and action plans, (ii) the number of companies with which there has been high-level engagement on the most severe human rights topics at headquarters completed with general information on the nature, purpose and results of these interactions and (iii) striving towards reporting on the total number of companies with which there has been interaction on human rights topics. ${ }^{105}$ Thus, banks had to report to the secretariat only and the secretariat did not have a monitoring function as in the Textile agreement. It has not been observed in evaluations if banks have benefitted from this secretariat function in terms of improvement of their OECD due diligence or material changes in their behaviour. On the contrary, the findings of the monitoring committee of the Banking agreement of 2019 reveal some adhering banks lack commitment, the overall targets are unlikely to be met at the end of the agreement term, amongst others because of different perspectives amongst signatories, perceived impediments of competition law (while the competent authorities are not asked for advice) and client confidentiality issues, which are taken as a given by adhering banks and not a starting point for further negotiations (either or not by using a clearing house to deal with confidential information). ${ }^{106}$ It may be a secretariat with functions comparable to the Textile agreement with an escalation option could have addressed (some of) these issues and may have rendered the agreement more effective. Furthermore, the two

103. Cf. ibid, pp. $79-82$ and 106.

104. See Art. 6.5 of the Banking agreement. This entails the information they ultimately have to provide, they have started to work towards this end result.

105. See Art. 6.5 of the Banking agreement. This should be in line with the GRI FS10 standard.

106. Seewww.imvoconvenanten.nl/ /media/imvo/mag/banken/20190705monitoring-progress-report-year2.pdf, pp. 31-5. An previous report has been issued in year one with comparable observations. Cf. KIT, Evaluation of the Dutch RBC Agreements, p. 70. 
consecutive interim reports from the monitoring committee have revealed comparable issues and, thus, the first report apparently did not bring about much change in the behaviour of business signatories. It has also been observed the forestry agreement and the vegetable protein agreement lack a compliance and monitoring mechanism and this is considered to be less effective. ${ }^{107}$

Thus, it is recommended to develop a secretariat function for all agreements which resembles the function of the Textile agreement (including an escalation option to binding dispute resolution), because it is most likely to enhance effective monitoring of compliance with the agreements and, thus, overall effectiveness of the agreements in bringing about material changes in behaviour of business signatories. This may increase cost, but I feel this is worth it and, as elaborated hereinabove, some options exist to limit this increase. An argument to introduce this type of secretariat function in other agreements may also be the legislation on child labour which is presumably coming into force in 2022. Section $5(4)$ of this Due diligence law on child labour ${ }^{108}$ holds the responsible minister may approve a shared due diligence plan to address child labour as developed by a multi-stakeholder initiative. It is likely such approval will only be given if the minister is confident the plan and multi-stakeholder initiative will bring about material change in business behaviour regarding child labour (which is included in OECD due diligence as implemented by most agreements) and may not approve initiatives where this is not clear. Thus, the minister may require effective monitoring of progress (and an escalation mechanism) for approval of an agreement. Beyond this, OECD due diligence in a more broad sense may become obligatory, for example, in Europe as has been announced by EU Commissioner Reynders. ${ }^{109}$ It is likely this legislation will include public supervision. Public supervisors may (partly) refrain from monitoring if businesses are signatory to an effective multi-stakeholder initiatives and public supervisors may require monitoring (and an escalation mechanism).

\subsubsection{No Impediment for Collaboration}

If the foregoing monitoring model and escalation mechanism would be implemented in other agreements one may wonder whether this may hamper proactive collaboration between signatories as this may trigger distrust and legal discussions which are not beneficial to realise impact 'on the ground' and achieve implementation of OECD due diligence. For example, as the monitoring committee of the Banking agreement has observed, drafting an IRBC agreement as a legal contract with involvement of many lawyers may not create mutual trust. ${ }^{110}$ However, actual compliance of individual sig-

107. IOB Report, pp. 53, 62 and 63.

108. Law of 24 October 2019, Stb. 2019, 401

109. See on this e.g. R. McCorquodale and M. Scheltema, Core Elements of an EU Regulation on Mandatory Human Rights \& Environmental Due Diligence, accessible through www.business-humanrights.org/en/ expert-contribution-core-elements-of-an-eu-regulation-on-mandatoryhuman-rights-environmental-due-diligence.

110. See pp. 34 and 35 of the report. natories is monitored and if necessary enforced by the secretariat of the Textile agreement. It emerges the way in which the secretariat performs this task is highly appreciated and perceived as support in implementing OECD due diligence. Many signatories observe they have learned from the support of the secretariat and have improved their due diligence. Thus, the Textile agreement may have performed best in making signatories implement OECD due diligence where they did not sufficiently do this before. However, it may make a difference whether only large companies/institutions which have the capacity to build expertise on their own are involved in the agreement or also smaller ones.

Beyond this, being a signatory to an agreement may also have legal consequences even if the agreement itself is not legally binding. For example, in connection with filling in open (tort) norms, judiciary may consider relevant whether a business is signatory to an agreement and, thus, voluntarily has committed itself to implement and undertake OECD due diligence. Monitoring and approval by a secretariat may convince the judiciary reasonable and appropriate OECD due diligence has been conducted. Therefore, no indications exist, making the agreements more binding and monitored by a secretariat on the individual company level makes these agreements less effective, on the contrary.

\subsubsection{At Least Continuous Improvement}

However, the foregoing does not necessarily imply the other agreements which do not avail a monitoring and escalation mechanism as the Textile agreement does do not contribute to better human rights compliance by its signatories at all. For example, it has been observed that compliance with standards one has contributed to may enhance compliance. ${ }^{111}$

In connection with this it may be important the agreements incentivise continuous improvement of human rights compliance and due diligence by the adhering (business) signatories. Most agreements seem to include such continuous improvement, but this is less clear for the Gold agreement. Beyond this, the agreements facilitate collaboration and discussion in an amicable setting between business and NGOs as has been elaborated in Section 3.3. In this setting NGOs may be prepared at least in certain cases to refrain from campaigning against companies with sometimes unrealistic demands and to engage in a more constructive dialogue to improve the human rights situation (in which parties agree to disagree). ${ }^{112}$ Beyond this, business entities may discuss these issues with their peers. Being confronted with the same type of issues may incentivise collaborative initiatives and learning. Outside the agreements this type of interaction between business peers may prove to be more difficult because of competition constraints. ${ }^{113}$

111. See e.g. Scheltema, p. 302

112. Cf. Proceeds Second Chamber 2017/18, 26 485, no. 253, pp. 3 and 4

113. However, this does not mean no competition issues could arise in connection with the agreements. Therefore, pursuant to Art. 5.4.4 of Textile agreement, Art. 14.8.a of the Banking agreement, Art. 11.10 of the Insurance agreement, Arts. 1.15 and 23.9 of the Pension Fund agree- 
That said, a monitoring and escalation mechanism of the Textile agreement seems to be able to bring about these changes faster and to a larger extent.

\subsection{Access to Remedy}

\subsubsection{Clarify Expectations on Access to Remedy}

It has emerged from the evaluations cited that access to remedy for external rights holders is the weakest part of the implementation of the IRBC agreements, as it is in connection with responsible business conduct, more generally speaking. ${ }^{114}$ Improvement is desirable in this arena.

To start with, the expectations in the agreements regarding access to remedy are not always clear. For example, whether meaningful engagement with (potentially) affected stakeholders and establishment of grievance mechanisms is part of due diligence required by the agreements is not elaborated (except for the Banking agreement in relation to the banks' clients and in the Insurance and Pension Fund agreements). The Banking agreement requires the banks to develop their own grievance and whistle-blower mechanisms for employees. ${ }^{115}$ They should also establish a grievance mechanism which allows third-party complaints. ${ }^{116}$ Furthermore, adhering banks will require their clients in project finance to implement a grievance mechanism and will promote the implementation of such mechanisms in connection with corporate lending if severe human rights violations are known to the adhering bank. ${ }^{117}$ The Insurance and Pension Fund Agreements include a similar provision, although they are broader as they do not require the insurers or pension funds to have knowledge of human rights violations by investee companies. ${ }^{118}$

For continuous learning within the agreements it would be helpful if banks, insurers or pension funds would also receive aggregated information about the number and nature of complaints in these mechanisms. However, this is far from easy as it would require contractual adaptations in loan (e.g. in the Loan Market Association models) and asset management agreements. Furthermore, the requirements regarding the functioning of these operational level grievance mechanisms are not clearly set. Beyond this, no agreements seem to cover measures a supplier is expected to take or has taken to remediate harm as part of the due diligence signatories to the agreements have to undertake.

ment, Art. 2.16 of the Gold agreement, Arts. 6.2 and 6.3 of the Metals agreement, Arts. 2.2.f, 2.2.g and Annex 4 of the Food agreement and Art. 2.5 of the TruStone agreement parties acknowledge their obligations under competition law. See on these issues e.g. J.J. Wubbels, Markt \& Mededinging 2016, Bju, pp. 193-98 and the letter of the Minister of Economic affairs to the chairperson of the Dutch Second Chamber about competition and sustainability of 23 June 2016, marked DGETM-MC/16071609 and Stcrt. 2016, number 52945.

114. Cf. KIT, Evaluation of the Dutch RBC Agreements, p. 116.

115. Art. 3.4 of the Banking agreement.

116. Art. 3.5 of the Banking agreement.

117. Art. 7.3 of the Banking agreement.

118. Arts. 6.2 and 6.4 of the Insurance agreement and Art. 8.2 of the Pension Fund agreement.
Clarifying expectations on access to remedy may assist in achieving better access to remedy. An example of this is a publication of the Banking agreement on how banks may contribute to providing access to remedy by their clients. ${ }^{119}$

\subsubsection{Binding Dispute Resolution Options}

Binding dispute resolution mechanisms are by and large perceived to be connected with legally binding agreements. Thus, the non-binding nature of most agreements may be reflected by the lack of binding dispute resolution options in these agreements. ${ }^{120}$ Only the Textile agreement includes a binding dispute resolution mechanism which allows third parties such as affected workers or communities to submit complaints about the compliance by the signatories to the agreement. Third parties may file complaints against adhering companies on non-compliance. The dispute resolution committee renders a binding decision on the complaint. ${ }^{121}$ However, before this complaint may be lodged, the complainant (or its representative) first has to try to solve the case amicably. ${ }^{122}$ Furthermore, the issue must be of material significance to the stakeholder individually or to the group to which he belongs to and one which he can substantiate in relation to the enterprise concerned on the basis of the content of the agreement, including the OECD Guidelines and the UNGPs. While a complaint is dealt with, all the parties involved will refrain from providing public information on the contents of the complaint and the complaint resolution process. The complaints committee ${ }^{123}$ will decide, having heard the parties, whether an adhering enterprise is acting in accordance with the agreement. The decision and its reasoning will be published, observing confidentiality where required for reasons of competition sensitivity and/or the protection of business confidentiality. ${ }^{124}$ The secretariat will monitor compliance with the decision as part of the assessment of the annual action plan of the enterprise involved. ${ }^{125}$ Furthermore, the Textile agreement includes provisions for providing information concerning a specific production site to the complaints committee on its request. The agreement itself states the secretariat shall in principle honour such a request and will inform the enterprise concerned of the nature of the complaint and the information supplied to the complaints committee. ${ }^{126}$ However, if a complaint against a

119. See for this www.imvoconvenanten.nl/-/media/imvo/files/banking/ paper-enabling-remediation.pdf?

la=en\&hash=4FB229CEBC0E8FCA85E5363240C11687.

120. See for the importance of proper conflict resolution mechanisms in connection with the cost of unresolved conflict Addressing Land Governance in International Responsible Business Conduct Agreements 2018 , p. 55.

121. See Art. 1.3 of the Textile agreement. Thus, it differs from the OECD NCP-specific instance mechanism as this will not result in binding decisions if parties to the dispute do not reach an agreement.

122. Art. 1.3 of the Textile agreement.

123. The author of this contribution is the chair of this committee.

124. Art. 1.3 of the Textile agreement.

125. Ibid.

126. Ibid. This procedure can be accessed through www.imvoconvenanten.nl/en/Textiles-textile/agreement/complaints. 
signatory is lodged with the dispute resolution mechanism it should pursuant to Article 25 of the procedural rules provide the information requested by the complaints committee itself instead of the secretariat. If the information is considered to be business sensitive or confidential, which has to be assessed by the deputy chair of the complaints committee, the complaints committee may only take notice of this information and use it in its decision; if the complainant agrees and accepts it will have no access to the information. ${ }^{127}$ Beyond this, procedural rules entail provisions to hear witnesses in such a way they are protected from retaliation and also envisage the use of an independent facilitator in exceptional cases. ${ }^{128}$ The Textile agreement also avails an informal (dialogue-based) mechanism connected to the production facility list of the agreement. If an external party has identified abuses at such a production location it may engage with the secretariat and if the secretariat has identified (multiple) signatories sourcing from that location it will send the complaint to them and will incentivise the company to liaise with the stakeholder and try to solve the issue. If unsuccessful or if the company does not take appropriate action, the complaint may be escalated to the complaint mechanism. ${ }^{129}$

Access to remedy for third parties remains weak in all other agreements as they do not include a mechanism which enables dispute resolution regarding third-party complaints.

\subsubsection{Challenges Regarding a Binding Dispute Resolution Mechanism}

Access to remedy may be challenging for third parties in the Textile agreement as to date few complaints have been lodged by third parties. ${ }^{130}$ This may point at hurdles in connection with its accessibility for these third parties. ${ }^{131}$ In connection with this it is observed that in the midterm evaluation of the Textile agreement the complaint mechanism is not used (by external stakeholders), not known even to many adhering companies and needs to be better communicated. ${ }^{132}$ Furthermore, it is observed the mechanism may not be UNGP 31 compliant as accessibility for external stakeholders is uncertain and limited, because it is unclear when an issue is of material significance as required by the procedural rules and how the existence of the mechanism is communicated to the very diverse group of external stakeholders. ${ }^{133}$ Beyond this, it is observed that it is not clear how a reasonable and equitable access to information, expertise and advice is secured for external parties, nor does the mechanism offer financial support for

\footnotetext{
127. See Art. 25 of the procedural rules.

128. Arts. 23 and 24 of the procedural rules.

129. This procedure may be accessed through www.imvoconvenanten.nl/ en/Textiles-textile/agreement/complaints.

130. See for pending cases and decisions of the panel www.imvoconvenanten.nl/en/Textiles-textile/agreement/complaints.

131. Cf. KIT, Evaluation of the Dutch RBC Agreements, p. 105.

132. See pp. 33 and 34 of the evaluation.

133. Duval and Partiti, p. 403. The requirement an alternative mechanism has to be used is abandoned since.
}

external complainants. ${ }^{134}$ It is also observed that hearings are not public, publication of decision is left to the discretion of the dispute resolution body. ${ }^{135}$ Thus, especially because of insufficient transparency the effectiveness of the dispute resolution process in terms of the UNGPs is considered to be weak at best and it would have been better to involve potentially affected stakeholders in the design of the mechanism. ${ }^{136}$ Although the decisions of the mechanism are published on the agreement website (also in English) and the panel has no discretion in this, it may take some time before these decisions provide sufficient clarity to external stakeholders. So in the design of future mechanisms within the agreements it may be helpful to involve external stakeholders and to better communicate it to enhance its effectiveness. That said, the binding mechanism of the Textile agreement seems at least more effective in terms of access to remedy than no complaint mechanisms for external stakeholders.

\subsubsection{Preferably Overarching Mechanism}

Thus, as elaborated hereinabove implementation of a comparable dispute resolution mechanism in the Textile agreement may enhance effectiveness of the other agreements. It would be even better to develop an overarching mechanism for all agreements, which by and large follows the design of the Textile agreement mechanism. This implies the dispute resolution panel exists with an independent chair and two sector experts, who are appointed by the NGO and business constituencies to the agreement respectively. This should be a fixed panel to enable it to render coherent decisions and build expertise in these types of disputes, except where conflicts of interest may arise. ${ }^{137}$ Globally binding dispute resolution on compliance with the OECD Guidelines or UNGP is quite unique and thus, coherence and expertise of the complaint committee members are important. It may be worthwhile to have an independent chair who resides over all disputes to enhance coherence and alignment in decisions regarding disputes arising from different agreements. This would also enable the panel to learn from issues in other agreements which may often be comparable and may require comparable solutions (sanctions). Thus, an overarching dispute resolution mechanism over the agreements would make them even more effective compared to such mechanisms for individual agreements. Because a pool of experts would exist, they may serve in disputes beyond their agreement if a conflict of interest arises with the agreement expert and this may reduce cost as no specific replacement for the agreement expert needs to be appointed. Cost may also be reduced because it would, for example, not be necessary to develop procedural rules for all the mechanisms of the different agreements.

\footnotetext{
134. Duval and Partiti, p. 403.

135. Ibid, p. 404.

136. Ibid.

137. In such cases experts from other agreements or the replacement of the chair may serve.
} 


\subsubsection{Need for Building 'Remedy Ecosystems'}

However, such a solution would still focus on an individual dispute resolution mechanism and not on remedy ecosystems consisting of a(n effective) combination of dispute resolution mechanism. The Textile agreement has adopted a combination of filing complaints with the secretariat regarding production facilities on the production facilities list (which does not display which signatory is sourcing from which facility). If a complaint is lodged, the secretariat refers the complaint to the signatory or signatories sourcing from this facility and informs the complainant of the binding dispute resolution mechanism if the signatory or signatories are not able to resolve the issue to the satisfaction of the complainant. ${ }^{138}$ However, even this feature still leaves room for doubt as to whether, for example, workers of these facilities will have sufficient access to such remote systems, for example, because of lack of knowledge of and trust in these mechanisms. Arguably, local mechanisms for these workers which are familiar to them and in which they trust may be more accessible. The binding mechanism in the Textile agreement may function as an escalation mechanism to these local mechanisms, for example, by resolving issues parties cannot agree upon in the local mechanism and after resolution of this issue refer the case back to the local mechanism. Obviously, the mechanism of the agreements can only perform its role if a signatory of the agreement is involved. However, this type of remedy eco-system is not yet deployed, but may contribute to more effective access to remedy. Fair Wear and the Textile agreement steering committee are currently exploring whether the local mechanisms of Fair Wear could provide such a local mechanism as a stage preceding the binding mechanism of the agreement. ${ }^{139}$

\section{Conclusion}

The International Responsible Business Conduct agreements have a joint background: the necessity identified by the Dutch government to reduce human rights-related risks in thirteen sectors. To date ten agreements have been concluded. The governance of these agreements is comparable and implements a tripartite collaboration between business, NGOs and the government. Most of them are aiming at implementing OECD due diligence and trying to bring about positive material change in the behaviour of business signatories in this regard. The two first agreements, the Textile and Banking agreements, have been described in more detail as an example of the other agreements.

The main purpose of this contribution has been to analyse the effectiveness of the agreements in terms of effective implementation and undertaking of OECD due diligence by business signatories and to provide recom-

138. See for this procedure www.imvoconvenanten.nl/en/Textiles-textile/ agreement/complaints.

139. See on this e.g. KIT, Evaluation of the Dutch RBC Agreements, p. 105. mendations for improvement. This analysis has been undertaken along the lines of three themes: (i) uptake, leverage and collaboration, (ii) implementation of OECD due diligence including monitoring and (iii) access to remedy.

In connection with uptake, leverage and collaboration it is important to notice IRBC agreements have not been concluded in all risk sectors, sometimes they only cover niches in a sector or do not include (a majority of) market actors. However, as the IRBC agreements are voluntary and their effectiveness is highly dependent on (proactive) collaboration between signatories, this may not be a sign of ineffectiveness per se. If the adhering parties are intrinsically motivated to comply with these standards, this may not necessarily hamper effectiveness. However, in terms of leverage a sufficient number of participants (also foreign companies) or collaboration between agreements seems important for their effectiveness. A further recommendation to enhance collaboration and synergy between the different agreements, which is improving but may be enhanced, is to identify topics as included in the SDGs to incentivise and enhance collaboration between agreements. In connection with this it may be advisable to establish an overarching government expert panel to supervise these processes and to advise on next steps.

In connection with due diligence, not all elements of OECD due diligence seem to be covered by the agreements and the implementation differs, also because some stakeholders, for example, in the Banking agreement, tried to introduce obligations beyond OECD due diligence. It is recommended to align the implementation of OECD due diligence, also to facilitate collaboration between agreements. Furthermore, an effective monitoring mechanism by a secretariat (hosted by SER) paired to a binding escalation mechanism, as is currently implemented in the Textile agreement only, is most likely to bring about material changes in business behaviour and is highly appreciated by (most) signatories to the Textile agreement. Other types of supervision seem less effective. Although introduction of monitoring and dispute resolution as deployed in the Textile agreement would lead to a more binding nature of most agreements, it is likely this will not hamper collaboration within these agreements, also because future legislation may (indirectly) require this type of monitoring. However, if such monitoring is not viable, the agreements should at least implement and supervise a continuous improvement model in connection with implementation of OECD due diligence.

Access to remedy is a challenge in all agreements. It is recommended to clarify expectations the agreements have on access to remedy, also in connection with the role of signatories to the agreements in cases where they are directly linked to human rights abuse, for example, by (indirect) suppliers. Only the Banking agreement has developed such clarification. Furthermore, it is recommended to introduce a dispute resolution mechanism comparable to that of the Textile agreement, which enables complaints for external stakeholders against 
business signatories. However, it is not recommendable to implement separate mechanisms in all agreements; it should be an overarching mechanism for all agreements. This would enable learning from issues in other agreements (which also involve OECD due diligence and may be comparable) as well as coherence in dispute resolution within the agreements. Such an overarching mechanism may also be less costly as, for example, not every agreement has to develop its own procedural rules. Furthermore, in order to enable access to the mechanism for external stakeholders it is advisable to create 'remedy ecosystems' consisting of a combination of mechanisms including local mechanisms (in countries where production locations are located) and escalation to the binding dispute resolution mechanism of the agreements. 